\title{
FREQUENCY DEPENDENCE OF THE IONOSPHERE SCINTILLATION PARAMETERS ON THE OBSERVATIONS OF COSMIC RADIO SOURCES AT THE DECAMETER WAVE RANGE
}

\author{
S. K. Panishko, O. A. Lytvynenko \\ Observatory URAN-4, Institute of Radio Astronomy NASU \\ Pushkinskaya str., 37, Odessa, 65125, Ukraine, spanishko@ukr.net
}

\begin{abstract}
When signal from radio source propagates through irregularity layer in the ionosphere it has fluctuations of the amplitude (scintillations) which time spectrum has power form with index $\alpha=3$. It was shown that such form of the time spectrum of amplitude fluctuations caused by power form of the spatial spectrum of electron concentration ionosphere irregularity with index $p=\alpha+1$, i.e. $p=4$. Based on theoretical preconditions for such form of the spatial spectrum the frequency dependence of scintillation index $m$ (scintillation intensity characteristic) was obtained in form power function: $m \propto$ $f^{-n}, \quad n=(p+2) / 4$, thus $n=1.5$. Similar frequency dependence of the scintillation index was observed experimentally for case of weak scintillations $(m<0.5)$. In this work the frequency dependence of scintillation parameters was analyzed on long-term observations of power cosmic radio sources on radio telescope URAN-4 at 20 and $25 \mathrm{MHz}$. The results were compared with results of earlier carried out investigations.
\end{abstract}

Key words: radio sources: ionosphere scintillations, decameter range, frequency dependence.

АНОТАЦІЯ. При проходженні сигналу від радіоджерела через неоднорідний шар в іоносфері виникають амплітудні флуктуації радіосигналу (мерехтіння), часовий спектр яких має степеневу форму 3 індексом $\alpha=3$. Було показано, що така форма часового спектру амплітудних флуктуацій випливає із форми просторового спектру іоносферних неоднорідностей електронної концентрації з індексом $p=\alpha+1$, тобто $p=4$. Виходячи із теоретичних припущень для такої форми просторового спектру була отримана частотна залежність індексу мерехтінь $m$ (характеристика інтенсивності мерехтінь) в формі степеневої функції: $m \propto f^{-n}$, $n=(p+2) / 4$, тобто $n=1.5$. Подібна частотна залежність індексу мерехтінь експериментально спостерігалась у випадку слабких мерехтінь $(m<0.5)$. В цій праці проаналізована частотна залежність параметрів мерехтінь по довготривалим спостереженням потужних космічних радіоджерел $(3 \mathrm{C} 144,3 \mathrm{C} 274,3 \mathrm{C} 405,3 \mathrm{C} 461)$ на радіотелескопі УРАН-4 на частотах 20 і 25 МГц з 1998 по 2007 рік. Індекс частотної залежності був вичислений із індексів мерехтінь, отриманих на двох частотах. Для всіх радіоджерел індекс $n$ не $є$ постійним, а залежить від величини індексу мерехтінь. Проаналізовані середні значення індексів частотної залежності, а також отриманих із них спектральних індексів $p$ для 4-х радіоджерел. Спектральні індекси $p$ були також вичислені i3 індексів $\alpha$, отриманих із спектрів іоносферних флуктуацій по записам спостережень радіоджерел. Порівняння цих величин між собою показало, що тільки для радіоджерела 3С405 результат співпадає 3 передбаченим теорією, яка допускає однократне розсіювання радіохвиль в іоносфері. Подібні результати були отримані в раніше проведених дослідженнях інших авторів і потребують щонайменше приймати до уваги такі фактори впливу як геометрія ефекту мерехтінь і багаторазове розсіювання радіохвиль.

Ключові слова: радіоджерело: іоносферні мерехтіння, декаметровий діапазон радіохвиль, частотна залежність

\section{Introduction}

When signal from cosmic radio source propagates in the inhomogeneous ionosphere it has fluctuations of intensity or scintillations. Scintillation effect can be characterized by scintillation index and time spectrum of fluctuations. Scintillation index defines as (Liu et al., 1986): $m=$ $\sqrt{(I(t)-\langle I\rangle)^{2} /\langle I\rangle^{2}}$, where $I$ - intensity of the received radio signal, angle brackets are the time averaging. Time spectrum of the intensity fluctuations has power shape with exponent $\alpha=3$ and caused by the power form of the spatial spectrum of the ionosphere plasma irregularities $\Phi_{\Delta N_{e}}(k) \propto$ $k^{-p}$ ( $k$ - wave number) with index (Yeh, 1982):

$$
p=\alpha+1 \text {. }
$$

Scintillations on the medium irregularities can originate under the conditions of strong and weak wave scattering (Franke, 1987). If $m \approx 1$, then scintillations are strong, saturated and if $m \ll 1$, (usually $m<0,5$ ) then scintillations are weak. The single scattering of the radio signal occurs at weak scintillations and radio signal suffers multiple scattering in a case of the saturated scintillations. Data interpretation complicates by absence of the analytic decisions for strong scintillations, the approximate methods are use in this case.

Ionosphere scintillations were observed in the range from $10 \mathrm{MHz}$ up to $6 \mathrm{GHz}(\mathrm{Wu}, 1983)$. For weak scintillations the frequency dependence was obtained as (Liu et al., 1986): $m \propto f^{-n}$. Thus scintillation effect is more significant as wave length of radio signal is larger. 


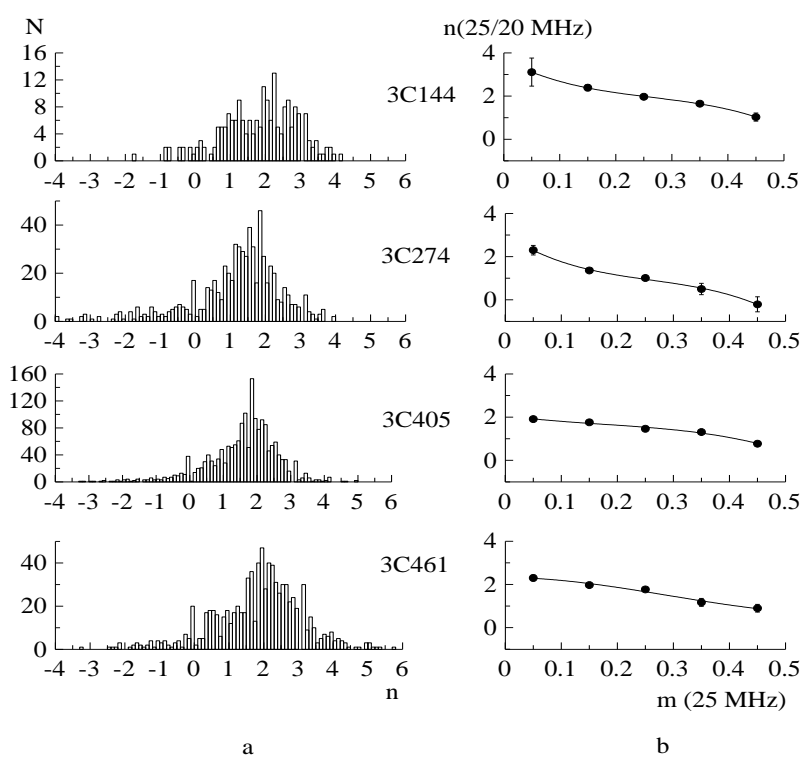

Figure 1: Behavior of the spectral index: a histograms; $b$ - dependences of the scintillation index (25 MHz), solid line - approximation by polynomial of the third order

Frequency dependence cannot be determinate in the case of saturated scintillations. Theoretical calculations associate spectral index $n$ with the spatial spectrum exponent $p$ as (Liu et al., 1986):

$$
n=(p+2) / 4 \text {. }
$$

In such case for power form of the spatial spectrum $n \approx$ 1,5 . In the present work the analysis of the ionosphere scintillation spectral indices calculated from scintillation indices obtained from observations of power radio sources at frequencies 20 and $25 \mathrm{MHz}$ was carried out.

\section{Observation data}

Ionosphere scintillation parameters were obtained from observations of power cosmic radio sources - 3C144, 3C274, 3C405, 3C461 which were carried out on the radio telescope URAN-4 during 1998-2007 at 20 and $25 \mathrm{MHz}$. Observation method and processing technique were considered in the works (Derevyagin et al., 2005; Panishko et al., 2019).

Index $\alpha$ can be determined on the slant part of the time power spectrum received from observation. Index $n$ can be derived on the index $\alpha$ from equation (1) and also index $n$ can be obtained from the scintillation index measured at two frequencies (equation (2)) as (Yeh et al., 1982):

$$
n\left(f_{1} / f_{2}\right)=-\log \left[m_{1}\left(f_{1}\right) / m_{2}\left(f_{2}\right)\right] / \log \left(f_{1} / f_{2}\right),
$$

where $f_{1}=25 \mathrm{MHz}, f_{2}=20 \mathrm{MHz}, m_{1}$ and $m_{2}$ scintillation indices on the corresponding frequencies.

Thus number of 3529 values of the spectral index was obtained with using observation records of good quality (without radio interferences) and analysis of this data will be considered in the next section.

\section{Results and their discussion}

Histograms of the spectral indices calculated from equation (3) are presented on the Fig. 1a for 4-th radio sources. The negative part is remarkable in all pictures that mean the larger values of scintillation index at the higher frequency. Similar result was obtained in the work (Rashkovsky, 2004) on the observations of the ionosphere scintillations of radio source $3 \mathrm{C} 405$ at the decameter radio wave range and this do not agree with theoretical concepts.

The dependence of spectral index $n$ from scintillation index $m$ at frequency $25 \mathrm{MHz}$ is shown on the Fig. 1b. Data for plots was obtained by meaning of index $n$ on scintillation index intervals with step 0.1 in limits from 0.01 up to 0.50 (weak scintillations). The dependence trend is emphasized by polynomial of the third order. From graphs you can see that the values of the spectral index do not stay constant and depend from scintillation index that coincide the case of the multiple radio wave scattering (Yeh et al, 1982). Also you can note that dependence for radio sources 3C405 and 3C461 is more sloping than for 3C144 and 3C274. Most likely that connected with the high on which radio source observed because the first sources located higher than the second and respectively the conditions of the scintillation occurrence are different (Panishko et al., 2019).

The mean values of the scintillation index and spectral index are presented in the Table 1 . You can note that values of the index $n$ and also $p$ are consistant with theoretical values for case of the single radio wave scattering only for 3C405 that was showed by results of the work (Rashkovsky, 2004). These values are remarkably larger for 3C144 and 3C461 and smaller for 3C274 than predicted by the theory. Estimations of the indices $p_{1}$ and $p_{2}$ obtained from the radio source records have less discrepancy with theoretical data however $3 \mathrm{C} 274$ also have the smaller values of the spectral index.

Table 1. Mean values of the scintillation parameters

\begin{tabular}{rrrrrrr}
\hline Source & $m_{1}$ & $m_{2}$ & $n$ & $p_{1}$ & $p_{2}$ & $p$ \\
\hline 3C144 & 0.29 & 0.42 & 1.8 & 3.7 & 3.4 & 5.4 \\
3C274 & 0.19 & 0.25 & 1.2 & 3.1 & 3.4 & 2.8 \\
3C405 & 0.20 & 0.28 & 1.6 & 4.6 & 4.6 & 4.3 \\
3C461 & 0.18 & 0.28 & 1.9 & 4.0 & 4.1 & 5.4 \\
\hline
\end{tabular}

\section{Conclusions}

From the observations of 4-th power radio sources on RT URAN-4 at 20 and $25 \mathrm{MHz}$ the values of the spectral index were obtained during 1998-2007. Frequency dependence differs for each source that means different conditions of scintillation occurrence. Interpretation of this data requires the attraction of many factors which influence on the results including multiple radio wave scattering and geometry of the scintillation effect.

\section{References}

Derevyagin V. G. et al.: 2005, Astron.\&Astrophys. Trans., 91, 421.

Franke F. J.: 1987, Radio Sci., 22, 643.

Liu C. H. et al.:1986, Radio Sci., 24, 363.

Panishko S. K. et al.: 2019, Radiofizika $i$ Radioastronomiya, 24, 44 (in Russian).

Rashkovsky S. L.: 2004, Izv.VUZov. Radiofizika, 47, 705 (in Russian).

Wu D. M.: 1983, Radio Sci., 18, 589.

Yeh K. C. et al.: 1982, Proc. IEEE, 70, 324. 